\title{
SYNTHESIS AND PHOTOOXYGENATION OF THE METHYL ESTER OF 11-HOMODRIM-6,8(9)-DIENE-12-OIC ACID
}

\author{
Andrei Bîrîiac \\ Institute of Chemistry of the Academy of Sciences of Moldova, Academy str. 3, MD-2028, Chisinau, Moldova \\ Tel: +37322739769, Fax: +37322739775, E-mail: andreib84@gmail.com
}

\begin{abstract}
Starting with the methyl 11-homodrim-8-ene-7-oxo-12-oate a two steps synthesis of methyl-11-homodrim-6,8(9)diene-12-oate was accomplished in $87 \%$ overall yield, which on photooxygenation in the presence of tetraphenylporphyrin gave a mixture of methyl esters of 11-homodrim-7-ene-6 $\alpha, 9 \alpha$-peroxy-12-oic and 11-homodrim-5,8-diene-7-oxo-12-oic acids $21 \%$ and $54 \%$ yields, respectively.
\end{abstract}

\section{Introduction}

Keywords: homodrimanes, synthesis, photooxygenation.

Drimanic sesquiterpenoids represent one of the largest groups of sesquiterpenoids, which continues to attract the attention of scientists due to their interesting and varied biological activity [1,2]. Commonly, polyfunctional compounds are more active, especially those with functional groups at the atoms C-6 and C-9, e.g. pereniporin A 1 and B 2 [3], cinnamodial (ugandensidial) 3 [4], cinnamosmolide 4 [5], mukaadial 5 [6] and albrassitriol 6 [7], than monofunctional ones (Figure 1).

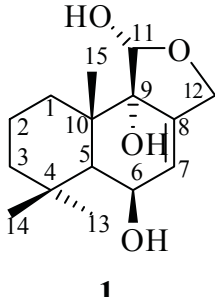

1<smiles>CC1(C)CCC[C@]2(C)[C@@H]3COC(=O)C3=C[C@@H](O)[C@@H]12</smiles>

$2 \mathrm{R}=\mathrm{H}$ $4 \mathrm{R}=\mathrm{AC}$<smiles>CC(=O)O[C@H]1C=C(C=O)[C@@](C)(O)[C@]2(C)CCCC(C)(C)C12</smiles>
3<smiles>CC1(C)CCC[C@@]2(C)C1[C@H](O)C=C(C=O)[C@@]2(C)O</smiles>

5<smiles>CC1=C[C@H](O)[C@H]2C(C)(C)CCC[C@]2(C)[C@]1(O)CO</smiles>

6<smiles>C/C(=C\CO)CC[C@H]1C(C(=O)O)=CCC2C(C)(C)CCC[C@@]21C</smiles>

7<smiles>CC1(C)CCC[C@]2(C)[C@@H](O)[C@@H]3O[C@]3(C)[C@H](CO)[C@H]12</smiles>

10<smiles>CC(=O)OCC1=CC[C@H]2C(C)(C)CCC[C@]2(C)[C@]12COC(=O)O2</smiles>

8<smiles>CC(=O)OCC1=CC(=O)[C@H]2C(C)(C)CCC[C@]2(C)[C@]12COC(=O)O2</smiles>

9<smiles>CC1=CCC2C(C)(C)CCC[C@@]2(C)[C@@H]1CO</smiles>

11<smiles>CC(=O)CC1=C(C)C(OC(C)=O)=C[C@@H]2C(C)(C)CCC[C@@]12C</smiles>

12<smiles>CC(=O)CC1=C(C)C(=O)C[C@H]2C(C)(C)CCC[C@]12C</smiles>

13

Figure 1

Because of the low content of sesquiterpenoids 1-6 and related compounds in natural sources, the interest of chemists turned to their synthetic preparation from easily available predecessors. However, it should be noted that carbon atoms C-6 and, especially, C-9 are sterically hindered and their direct functionalization is difficult. This is possible to do via complicated synthesis in moderate overall yields. For example, pereniporin A 1 was obtained in 11 steps from available zamoranic acid 7 in 4\% overall yield [8]. The introduction of keto group in position C-6 was possible only in some cases, for example, in compound $\mathbf{8}$, which was oxidized with $\mathrm{CrO}_{3}$ in acetic acid in compound $\mathbf{9}$ in a moderate yield $(52 \%)[9]$. C-6 in 8 steps.

Thus, the authors [10] on synthesis of uvidine C $\mathbf{1 0}$ from drimenol $\mathbf{1 1}$ introduced hydroxyl group in position

Considering the above, we attempted to develop a method of simultaneous functionalization of atoms C-6 and C-9 in the cycle B of an available norlabdanic compound, containing conjugated 1,3-dienic system at C-6-C-7 and C-8-C-9 carbon atoms, using the reaction of photolytic [4+2] cycloaddition of singlet oxygen to dienic system. 


\section{Results and discussion}

Earlier, for elaboration of a short method of simultaneous functionalization of the carbon atoms C-6 and C-9 in the series of 11-homodrimanic compounds, the photooxygenation reaction of the enolacetate 12, prepared from ketoester 13, was studied [11]. The latter one was prepared by oxidation of the mixture of known esters $\mathbf{1 4}$ [12, 13].

According to literature data 1,3-dienic compounds react with singlet oxygen giving endoperoxides by [4+2] cycloaddition reaction [14-16]. However, the reaction product of enolester 12 with singlet oxygen was not the expected endoperoxide 15 but the dienone 16. This result can be explained by the fact that the dienic system of compound $\mathbf{1 2}$ contains the electron-reach C-6-C-7 double bond, which reacts with electrophilic singlet oxygen giving the perepoxyde 17. The addition of the singlet oxygen to this double bond occurs from sterically more accesible $\alpha$-side of the molecule (see Figure 2).<smiles>C=C1C=CC2C(C)(C)CCC[C@]2(C)C1CC(C)=O</smiles>

14

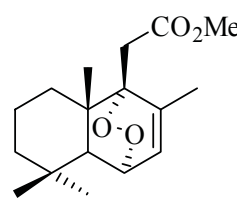

15<smiles>CC(=O)CC1=C(C)C(=O)C=C2C(C)(C)CCC[C@@]21C</smiles>

16

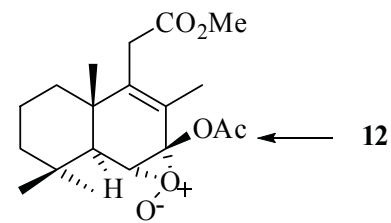

17

Figure 2

Taking into account the above mentioned data, it was of interest to carry out the synthesis of compound $\mathbf{1 8}$ with conjugated double bonds in cycle B and then investigate its behavior in photochemical process. Ketoester $\mathbf{1 3}$ served as the starting compound for the preparation of dienic ester 18 (scheme 1).

Compound $\mathbf{1 3}$ was reduced with sodium borohydride in the presence of cerium trichloride giving the methyl ester of 11-homodrim-8-ene-73-ol-12-oic acid 19 in the $98 \%$ yield. The structure of compound 19 was elucidated on the base of its spectral data. In particular, the width the of proton's signal at $\mathrm{C}-7$ on its half-height $\left(\mathrm{W}_{1 / 2}=7.62 \mathrm{~Hz}\right)$ and its multiplicity (triplet, $J=8.6 \mathrm{~Hz}$ ) indicate that hydroxyl group at C-7 is equatorially oriented.

On dehydration of hydroxyester 19 under mild conditions with concentrated $\mathrm{H}_{2} \mathrm{SO}_{4}$ solution in THF the methyl ester of 11-homodrim-6,8(9)-diene-12-oic acid $\mathbf{1 8}$ was obtained in 89\% yield. Its IR-spectrum exhibited bands for the ester group at 1155 and 1746 and the dienic system at 2860 and $750 \mathrm{~cm}^{-1}$. In its ${ }^{1} \mathrm{H}-\mathrm{NMR}$ spectrum there are present the signals of five methyl groups: three of them bonded to quaternary carbon atoms C-4 and C-10 at $0.91,0.93$ and 0.78 ppm (H-14, H-15 and H-16, respectively), methyl group attached to C-8 (1.71 ppm) and methyl ester group at $3.65 \mathrm{ppm}$, doublet signals of protons at the double bond C-6-C-7 appear as doublet of doublet at $5.85 \mathrm{ppm}(\mathrm{H}-6)$ and $5.76 \mathrm{ppm}(\mathrm{H}-$ 7) and the doublet signal of $\mathrm{H}-5$ proton at $2.03 \mathrm{ppm}$. The ${ }^{13} \mathrm{C}-\mathrm{NMR}$ spectrum also confirms the structure of ester 18. It contains the signals of five methyl groups at $51.7,32.3,22.6,18.1$ and $14.9 \mathrm{ppm}$, of quaternaty carbon atoms C-8 (127.8 ppm), C-7 (128.1 ppm), 129.1 ppm (C-6), 136.0 ppm (C-9) and 172.8 ppm (the carbonyl group C-12).

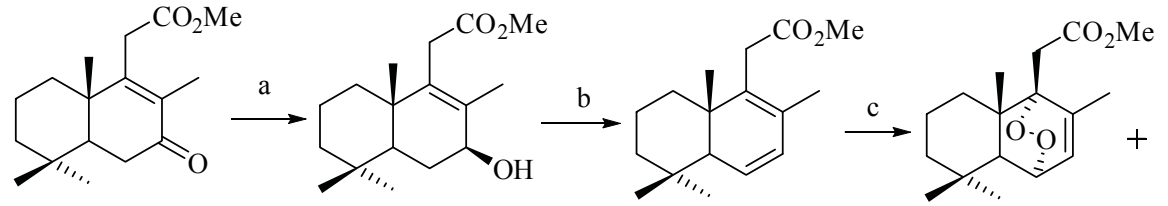

19
18

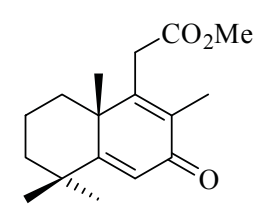

16

Scheme 1. Reagents: (a) $\mathrm{NaBH}_{4}, \mathrm{CeCl}_{4} * 7 \mathrm{H}_{2} \mathrm{O}, \mathrm{MeOH}$, r.t., $0.5 \mathrm{~h}, 98 \%$; (b) $\mathrm{H}_{2} \mathrm{SO}_{4}$, THF, r.t., 24h, $89 \%$; (c) hv, $\mathrm{O}_{2}$, TPP, DCM, $5{ }^{\circ} \mathrm{C}, 5 \mathrm{~h}, 21 \%(15)$ and $54 \%(16)$

The photooxygenation of dienic ester $\mathbf{1 8}$ was carried out in dichloromethane solution of in the presence of tetraphenylporphyrin. According to TLC data the reaction product represented a complex mixture of compounds with two major components which were separated by column chromatography on silica gel. The first compound eluted from column was the endoperoxide $\mathbf{1 5}$, obtained in $21 \%$ yield (scheme 1). In the IR-spectrum of compound $\mathbf{1 5}$ there are bands characteristics for ester group $\left(1730\right.$ and $\left.1167 \mathrm{~cm}^{-1}\right)$ and endoperoxyde group at $1107 \mathrm{~cm}^{-1}$. Its ${ }^{1} \mathrm{H}$-NMR spectrum displays signals of five methyl groups, two of them at 1.04 and $0.79 \mathrm{ppm}$ bonded to C-4, $0.92 \mathrm{ppm}$ bonded to C-10, $1.99 \mathrm{ppm}$ bonded to C-8 and signal of methyl ester group at $3.66 \mathrm{ppm}$. At $6.33 \mathrm{ppm}$ was present the doublet of doublet of $\mathrm{H}-7$ atom and at $4.49 \mathrm{ppm}$ of H-6 atom. The doublet signal of $\mathrm{H}-5$ appears at $1.72 \mathrm{ppm}$. In ${ }^{13} \mathrm{C}-\mathrm{NMR}$ spectrum of compound 15 there are signals of carbon atoms C-8 at $141.8 \mathrm{ppm}, \mathrm{C}-7$ at $125.7 \mathrm{ppm}, \mathrm{C}-9$ at $86.3 \mathrm{ppm}, \mathrm{C}-6$ at $72.3 \mathrm{ppm}$ and of the ester group carbonyl at $169.9 \mathrm{ppm}$. The ${ }^{13} \mathrm{C}-\mathrm{NMR}$ spectra contain also the signals of five methyl groups at $51.7\left(\mathrm{CO}_{2} \mathrm{Me}\right.$ ), 31.8 (C-15), 24.3 (C-14), 21.3 (C-13) and 20.1 (C-16). Unfortunately, the yield of target endoperoxide 15 was low. All attempts to increase it, changing the reaction condition, failed. The use of rose bengal and methylene blue as photosensitizer did not lead to an increase of the compound $\mathbf{1 5}$ yield. 
The next compound eluted from chromatographic column was the known methyl ester of 11-homodrim5,8(9)-diene-7-one-12-oic acid 16 (54\% yield), which was identified by comparing with its authentic sample obtained earlier [11]. A possible way of the dienone $\mathbf{1 6}$ formation from dienic ester $\mathbf{1 8}$ is depicted in scheme 2.

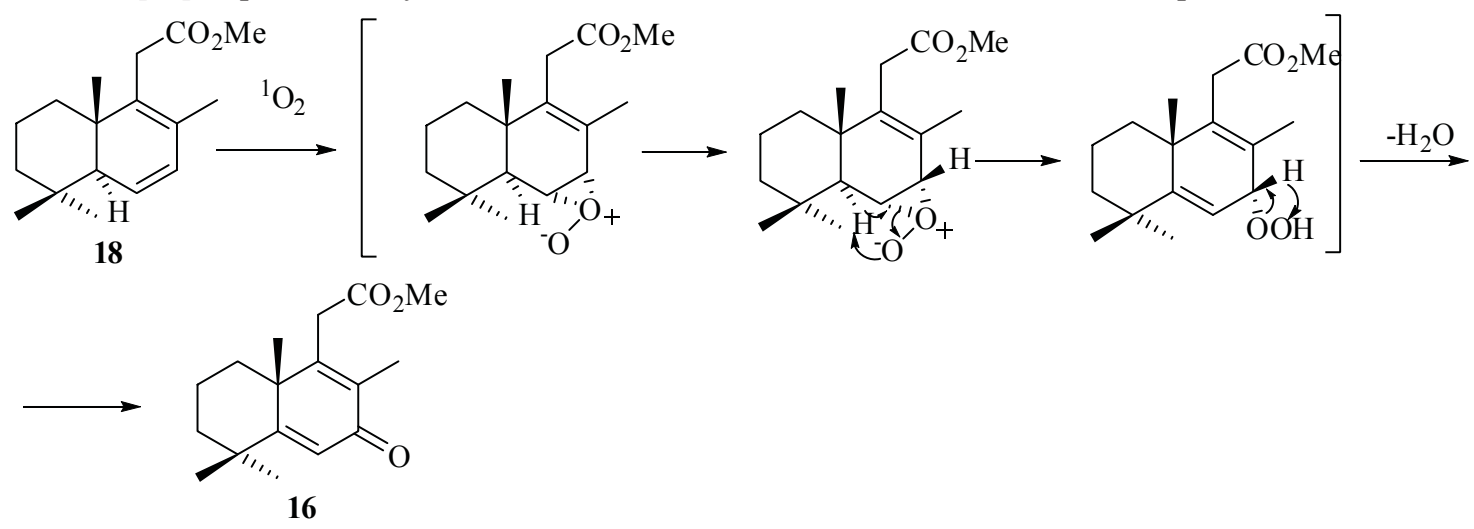

Scheme 2

The reduction of endoperoxide 15 with thioureea in $\mathrm{MeOH}$ leads the methyl ester of 11-homodrim-7-ene$6 \alpha, 9 \alpha$-diol-12-oic acid 20 in 96\% yield (scheme 3). This step was carried out with the aim to obtain a more stable 6,9-disubstituted homodrimanic compound. Its IR spectrum contains characteristic bands for ester $\left(1160\right.$ and $\left.1710 \mathrm{~cm}^{-1}\right)$ and hydroxyl (3420 and $1205 \mathrm{~cm}^{-1}$ ) groups. In ${ }^{1} \mathrm{H}-\mathrm{NMR}$ spectrum of compound 20 there are present the doublet signal of the H-7 proton (5.48 ppm), doublet of doublet of the H-6 proton (4.04 ppm) and the signals of five methyl groups at $3.69 \mathrm{ppm}\left(\mathrm{CO}_{2} \mathrm{Me}\right), 1.68 \mathrm{ppm}(\mathrm{H}-13), 1.14 \mathrm{ppm}(\mathrm{H}-15), 1.04 \mathrm{ppm}(\mathrm{H}-16)$ and $0.88 \mathrm{ppm}(\mathrm{H}-14)$. In ${ }^{13} \mathrm{C}-\mathrm{NMR}$ spectrum of compounds 20 there are also present the signals of completely substituted carbon atoms at C-4 (32.9 ppm) and C-10 (43.6), signal of tertiary C-5 atom (49.2 ppm) and signals of methylenic atoms C-1 (33.1), C-2 (18.7 ppm), C-3 (42.9 ppm) and C-11 (38.9 ppm).

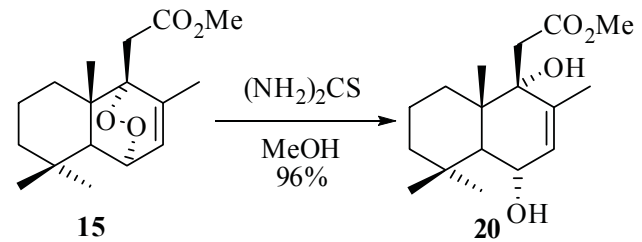

Scheme 3

\section{Conclusion}

Starting with the methyl 11-homodrim-8-ene-7-one-12-oate a two steps synthesis of the methyl 11-homodrim6,8(9)-diene-12-oate was accomplished in $87 \%$ overall yield. The photooxygenation of this compound in the presence of tetraphenylporphyrin led to the mixture of methyl 11-homodrim-7-ene-6 $\alpha, 9 \alpha$-peroxy-12-oate and methyl 11-homodrim5,8-diene-7-one-12-oate in $21 \%$ and $54 \%$ yields, respectively. These esters are valuable intermediate in the synthesis of physiologically active drimanic and norlabdanic derivatives.

\section{Experimental}

Melting points (mp) were determined on a Boetius hot stage. Optical rotations were measured on a Perkin-Elmer 241 polarimeter with a $1 \mathrm{dm}$ microcell, in $\mathrm{CHCl}_{3}$. IR spectra were recorded on Bio-Rad-Win-IR and Perkin-Elmer Models spectrometer. ${ }^{1} \mathrm{H}$ and ${ }^{13} \mathrm{C}$ NMR spectra were recorded in $\mathrm{CDCl}_{3}$ on Bruker AC-E 200 (200 and $50 \mathrm{MHz}$ ) and Bruker Avance DRX 400 (400 and $100 \mathrm{MHz}$ ) spectrometers. Chemical shifts are given in parts per million values in $\delta$ scale with $\mathrm{CHCl}_{3}$ as internal standard ( $\delta$ at 7.26 ppm for proton and $\delta 77.00$ ppm for carbon) and coupling constants in Hertz. H,H-COSY, H,C-HSQC and H,C-HMBC experiments were recorded using standard pulse sequences, in the version with $z$-gradients, as delivered by Bruker. Carbon substitution degrees were established by DEPT pulse sequence. Mass spectra (MS) were run on an AEI MS 902 spectrometer (EI, $70 \mathrm{eV}$ ). For analytical TLC, Sorbfil silica-gel plates were used. The chromatograms were sprayed with conc. $\mathrm{H}_{2} \mathrm{SO}_{4}$ and heated at $80^{\circ} \mathrm{C}$ for $5 \mathrm{~min}$ to detect the spots. Column chromatography was carried out on Across silica gel (60-200 mesh) using petroleum ether (PE) (bp 40-60 $\left.{ }^{\circ} \mathrm{C}\right)$ and the gradient mixture of petroleum ether and EtOAc. All solvents were purified and dried by standard techniques before use. Crude products in organic solvents were dried over anhydrous $\mathrm{Na}_{2} \mathrm{SO}_{4}$, filtered, and evaporated under reduced pressure.

Methyl ester of 11-homodrim-8-ene-7ß-ol-12-oic acid 19. To a stirred solution of $\mathrm{CeCl}_{3} \cdot 7 \mathrm{H}_{2} \mathrm{O}(671 \mathrm{mg}$, $1.80 \mathrm{mmol})$ in $\mathrm{MeOH}(5 \mathrm{~mL})$ at $18^{\circ} \mathrm{C}$ the solution of keto ester $13(500 \mathrm{mg}, 1.80 \mathrm{mmol})$ in $\mathrm{MeOH}(10 \mathrm{ml})$ was added. After 3 min $\mathrm{NaBH}_{4}(68 \mathrm{mg}, 1.80 \mathrm{mmol}$ ) was added and the mixture was stirred at the same temperature for $0.5 \mathrm{~h}$ (TLC control). The reaction mixture was treated with cold $5 \% \mathrm{HCl}$ solution $(5 \mathrm{~mL})$, and after dissolution of the precipitate it was extracted with diethyl ether $(3 \times 25 \mathrm{~mL})$. The extract was washed with water $(2 \times 15 \mathrm{~mL})$ and dried. After removal 
of the solvent in vacuum the crude product $(510 \mathrm{mg})$ was purified by column chromatography on silica gel (25 g, eluent: $\mathrm{PE} /$ EtOAc 85:15), to give the methyl ester of 11-homodrim-8-ene-7 $\beta$-ol-12-oic acid 19 (492 mg, yield 98\%) as a white crystals, mp $106^{\circ}-107^{\circ} \mathrm{C}$ (from PE), $[\alpha]_{\mathrm{D}}{ }^{20}+50.8^{\circ}\left(\mathrm{CHCl}_{3}, \mathrm{c} 0.03\right)$. IR $\left(v, \mathrm{~cm}^{-1}\right): 3493,1146(\mathrm{OH}), 1733\left(\mathrm{CO}_{2} \mathrm{Me}\right) .{ }^{1} \mathrm{H}$ NMR $\left(400 \mathrm{MHz}, \delta_{\mathrm{H}}, \mathrm{ppm}\right) 4.15\left(1 \mathrm{H}, \mathrm{t}, J 8.6 \mathrm{~Hz}, \mathrm{~W}_{1 / 2} 7.62 \mathrm{~Hz}, H-7\right), 3.68\left(3 \mathrm{H}, \mathrm{s}, \mathrm{CO}_{2} M e\right), 3.09(1 \mathrm{H}, \mathrm{d}, J 17.0 \mathrm{~Hz}), 2.99$ $(1 \mathrm{H}, \mathrm{d}, J 17.0 \mathrm{~Hz})\left(\mathrm{AB}-s y s t e m \mathrm{C}(11) \mathrm{H}_{2}\right), 2.12(1 \mathrm{H}, \mathrm{ddd}, J 14.0,7.4,6.2 \mathrm{~Hz}, H-6), 1.67(3 \mathrm{H}, \mathrm{s}, H-13), 1.25(1 \mathrm{H}, \mathrm{m}$, $H-5), 1.00(3 \mathrm{H}, \mathrm{s}, H-16), 0.89$ (3H, s, $H-15), 0.85$ (3H, s, $H-14) .{ }^{13} \mathrm{C}$ NMR $\left(100.61 \mathrm{MHz}, \delta_{\mathrm{C}}, \mathrm{ppm}\right): 172.8(\mathrm{C}-12), 137.8$ (C-9), 132.7 (C-8), 72.9 (C-7), 51.8 ( $\left.\mathrm{CO}_{2} \mathrm{Me}\right), 49.5$ (C-5), 41.2 (C-6), 39.4 (C-10), 35.9 (C-11), 33.0 (C-1), 32.9 (C-15), 32.8 (C-4), 29.7 (C-3), 21.5 (C-14), 19.7 (C-13), 18.7 (C-2), 15.5 (C-16); HRMS m/z (EI): found 280.20344. $\mathrm{C}_{17} \mathrm{H}_{28} \mathrm{O}_{3}$ requires 280.20384. $280\left(\mathrm{M}^{+}, 14\right), 221$ (5), 207 (25), 191 (8), 173 (9), 157 (25), 135 (11), 124 (100), 109 (65), 96 (29), 81 (14), 69 (24), 55 (31), 41 (40).

Methyl ester of 11-homodrim-6,8(9)-diene-12-oic acid 18. To a solution of hydroxyester 19 (250 mg, 0.89 $\mathrm{mmol})$ in THF $(4 \mathrm{~mL})$ the solution of concentrated $\mathrm{H}_{2} \mathrm{SO}_{4}(0.16 \mathrm{~mL})$ in THF $(0.84 \mathrm{~mL})$ was added and the obtained mixture was stirred for $24 \mathrm{~h}$ at room temperature, diluted with water $(10 \mathrm{~mL})$ and extracted with ether $(3 \mathrm{x} 15 \mathrm{~mL})$. The organic layer was washed with water $(2 \times 20 \mathrm{~mL})$ and dried. The removal of the solvent afforded an yellow oil $(247$ $\mathrm{mg})$, which was purified by column chromatography on silica gel ( $5 \mathrm{~g}$, eluent: PE/EtOAc 95:5), to give the methyl ester of 11-homodrim-6,8(9)-diene-12-oic acid 18 as white crystals $(208 \mathrm{mg}, 89.0 \%), \mathrm{mp} 55-56^{\circ} \mathrm{C}$ (from $\left.\mathrm{PE}\right),[\alpha]_{\mathrm{D}}{ }^{22}+67.8^{\circ}$ $\left(\mathrm{CHCl}_{3}, \mathrm{c} 1.17\right)$. IR $\left(v, \mathrm{~cm}^{-1}\right): 2860(\mathrm{C}=\mathrm{C}), 1746,1155\left(\mathrm{CO}_{2} \mathrm{Me}\right), 750(=\mathrm{C}-\mathrm{H}) .{ }^{1} \mathrm{H}$ NMR $\left(400 \mathrm{MHz}, \delta_{\mathrm{H}}, \mathrm{ppm}\right) 5.85(1 \mathrm{H}$, dd, J 2.95, $9.30 \mathrm{~Hz}, H-6), 5.76(1 \mathrm{H}, \mathrm{dd}, J 3.16,9.30 \mathrm{~Hz}, H-7), 3.65\left(3 \mathrm{H}, \mathrm{s}, \mathrm{CO}_{2} M e\right), 3.13(1 \mathrm{H}, \mathrm{d}, J 16.0 \mathrm{~Hz}), 3.02(1 \mathrm{H}, \mathrm{d}$, $J 16.0 \mathrm{~Hz})\left(\mathrm{AB}-\mathrm{system}, \mathrm{C}(11) \mathrm{H}_{2}\right), 2.03(1 \mathrm{H}, \mathrm{d}, J 2.9 \mathrm{~Hz}, H-5), 1.71(3 \mathrm{H}, \mathrm{s}, H-13), 0.93(3 \mathrm{H}, \mathrm{s}, H-15), 0.91(3 \mathrm{H}, \mathrm{s}, H-14)$, $0.78(3 \mathrm{H}, \mathrm{s}, H-16) .{ }^{13} \mathrm{C}$ NMR $\left(100.61 \mathrm{MHz}, \delta_{\mathrm{C}}, \mathrm{ppm}\right): 172.8$ (C-12), $136.0(\mathrm{C}-9), 129.1$ (C-6), 128.1 (C-7), $127.8(\mathrm{C}-8)$, 52.4 (C-5), 51.7 ( $\left.\mathrm{CO}_{2} \mathrm{Me}\right), 40.8$ (C-3), 38.7 (C-10), 35.1 (C-1), 33.1 (C-4), 32.5 (C-11), 32.3 (C-15), 22.6 (C-14), 18.8 (C-2), 18.1 (C-13), 14.9 (C-16). HRMS m/z (EI): found 262.19356. $\mathrm{C}_{17} \mathrm{H}_{26} \mathrm{O}_{2}$ requires 262.19328. m/z $262\left(\mathrm{M}^{+}, 27\right), 203$ (7), 191 (13), 173 (63), 159 (10), 145 (19), 133 (36), 119 (100), 105 (16), 91 (20), 83 (13), 69 (10), 55 (26), 41 (35).

Methyl esters of 11-homodrim-7-ene-6a,9 $\alpha$-peroxy-12-oic 15 and 11-homodrim-5,8-diene-7-one-12-oic 16 acids. To a stirred solution of diene $18(240 \mathrm{mg}, 0.92 \mathrm{mmol})$ in $25 \mathrm{~mL}$ of $\mathrm{CH}_{2} \mathrm{Cl}_{2}$ was added $2 \mathrm{mg}$ of tetraphenylporphyrin (TPP). The resulting mixture was irradiated with two bulb lumps (100 W each) while oxygen was passed through stirred solution at $5{ }^{\circ} \mathrm{C}$ for $5 \mathrm{~h}$. Evaporation of the solvent at the reduced pressure and chromatography of the residue (311 mg)

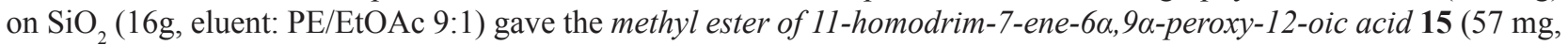
$21 \%$ ), white crystals, mp $116-117^{\circ} \mathrm{C}$ (from PE), $[\alpha]_{\mathrm{D}}^{23}+11.95^{\circ}\left(\mathrm{CHCl}_{3}, c 0.21\right)$. IR $\left(v, \mathrm{~cm}^{-1}\right): 1733,1167\left(\mathrm{CO}_{2} \mathrm{Me}^{23}, 1198\right.$ (peroxy group). ${ }^{1} \mathrm{H}$ NMR $\left(400 \mathrm{MHz}, \delta_{\mathrm{H}}, \mathrm{ppm}\right): 6.33(1 \mathrm{H}, \mathrm{dd}, J 6.0,1.6 \mathrm{~Hz}, H-7), 4.49(1 \mathrm{H}, \mathrm{dd}, J 10.5,6.0 \mathrm{~Hz}, H-6), 3.66$ $\left(3 \mathrm{H}, \mathrm{s}, \mathrm{CO}_{2} \mathrm{Me}\right), 2.82(1 \mathrm{H}, \mathrm{d}, J 15.8 \mathrm{~Hz}), 2.59(1 \mathrm{H}, \mathrm{d}, J 15.8 \mathrm{~Hz})\left(\mathrm{AB}-\mathrm{system}, \mathrm{C}(11) \mathrm{H}_{2}\right), 1.99(3 \mathrm{H}, \mathrm{s}, H-13), 1.72(1 \mathrm{H}, \mathrm{d}$, $J 12.08 H-5), 1.04(3 \mathrm{H}, \mathrm{s}, H-15), 0.92(3 \mathrm{H}, \mathrm{s}, H-16), 0.79(3 \mathrm{H}, \mathrm{s}, H-14) .{ }^{13} \mathrm{C}$ NMR $\left(100.61 \mathrm{MHz}, \delta_{\mathrm{C}}, \mathrm{ppm}\right): 169.9(\mathrm{C}-12)$, 141.8 (C-8), 125.7 (C-7), 86.3 (C-9), 72.3 (C-6), 51.9 (C-5), 51.7 (CO $\left.\mathrm{CO}_{2}\right), 45.3$ (C-10), 38.8 (C-3), 32.2 (C-4), 32.0 (C-11), 31.8 (C-15), 30.5 (C-1), 24.3 (C-14), 21.3 (C-13), 20.1 (C-16), 18.6 (C-2). HRMS m/z (EI): found 294.18231. $\mathrm{C}_{17} \mathrm{H}_{26} \mathrm{O}_{4}$ requires 294.18311.262 [( $\left(\mathrm{M}^{+}-32,10\right), 205$ (3), 193 (18), 187 (19), 173 (29), 151 (10), 133 (20), 119 (44), 109 (95), 95 (57), 81 (54), 69 (78), 55 (54), 41 (100).

The next compound eluted from column with the same solvent system was the known methyl ester of

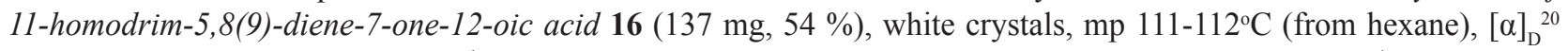
$+50.80^{\circ}\left(\mathrm{CHCl}_{3}, c 6.31\right)$. IR $\left(\mathrm{v}, \mathrm{cm}^{-1}\right): 1715,1167\left(\mathrm{CO}_{2} \mathrm{Me}\right), 1637,1614$ (dienone group), $826\left(>\mathrm{C}=\mathrm{C}<{ }_{\mathrm{H}}\right) .{ }^{1} \mathrm{H} \mathrm{NMR}(400$ $\left.\mathrm{MHz}, \delta_{\mathrm{H}}\right) 6.31(1 \mathrm{H}, \mathrm{s}, H-6), 3.68\left(3 \mathrm{H}, \mathrm{s}, \mathrm{CO}_{2} \mathrm{Me}\right), 3.43(1 \mathrm{H}, \mathrm{d}, J 16.9 \mathrm{~Hz}), 3.31(1 \mathrm{H}, \mathrm{d}, J 16.9 \mathrm{~Hz})(\mathrm{AB}-\mathrm{system}, \mathrm{C}(11)$ $\left.\mathrm{H}_{2}\right), 1.84(3 \mathrm{H}, \mathrm{s}, H-13), 1.28(3 \mathrm{H}, \mathrm{s}, H-16), 1.27(3 \mathrm{H}, \mathrm{s}, H-15), 1.20(3 \mathrm{H}, \mathrm{s}, H-14) .{ }^{13} \mathrm{C} \mathrm{NMR}\left(100.61 \mathrm{MHz}, \delta_{\mathrm{C}}\right): 186.5$ (C-7), 171.9 (C-5), 170.3 (C-12), 154.8 (C-9), 133.3 (C-8), 123.7 (C-6), 52.1 (CO $M e), 43.6$ (C-10), 40.1 (C-3), 37.2 (C-1), 34.9 (C-4), 34.3 (C-11), 32.3 (C-15), 28.5 (C-14), 25.2 (C-16), 18.1 (C-2), 11.6 (C-13). HRMS m/z (EI): found 276.17209. $\mathrm{C}_{17} \mathrm{H}_{24} \mathrm{O}_{3}$ requires 276.17254.276. $\left(\mathrm{M}^{+}, 100\right), 261$ (22), 244 (17), 233 (53), 220 (26), 203 (89), 189 (30), 174 (61), 159 (69), 147 (33), 133 (20), 119 (44), 105 (33), 91 (42), 81 (18), 69 (48), 55 (46), 41 (78).

Methyl ester of 11-homodrim-7-ene-6a,9 $\alpha$-diol-12-oic acid 20. To a solution of the endoperoxyde 15 (55 $\mathrm{mg}, 0.19 \mathrm{mmol})$ in $\mathrm{MeOH}(1.5 \mathrm{~mL})$ was added during 10 minutes at the room temperature solution of thioureea (29 $\mathrm{mg}$, $0.37 \mathrm{mmol})$ in $\mathrm{MeOH}(1 \mathrm{~mL})$. Reaction mixture was stirred $3 \mathrm{~h}$ at room temperature, then diluted with water $(25 \mathrm{~mL})$ and extracted with diethyl ether $(3 \times 25 \mathrm{ml})$. After drying of solution and solvent removing the crud product (58 mg) was subjected to column chromatography on silica gel (5 g, eluent: PE/EtOAc 8:2) to give methyl ester of 11-homodrim-7ene-6 $\alpha, 9 \alpha$-diol-12-oic acid 20 (55 mg, 96\%) as an oil; $\left.[\alpha]_{\mathrm{D}}^{20}=-5.74^{\circ}(c) 2.3\right)$; IR ( $\left.\mathrm{v}, \mathrm{cm}^{-1}\right) v_{\max }$ (film): $3420,1205(\mathrm{OH})$, 1710, $1160\left(\mathrm{CO}_{2} \mathrm{Me}\right),{ }^{1} \mathrm{H}$ NMR $\left(400 \mathrm{MHz}, \delta_{\mathrm{H}}\right): 5.48(1 \mathrm{H}, \mathrm{dd}, J 5.2,2.0 \mathrm{~Hz}, H-7), 4.04(1 \mathrm{H}, \mathrm{dd}, J 10.0,2.0 \mathrm{~Hz}, H-6), 3.69$ $\left(3 \mathrm{H}, \mathrm{s}, \mathrm{CO}_{2} \mathrm{Me}\right), 2.54(1 \mathrm{H}, \mathrm{d}, J 16.0 \mathrm{~Hz}), 2.46(1 \mathrm{H}, \mathrm{d}, J 16.0 \mathrm{~Hz})\left(\mathrm{AB}-\mathrm{system} \mathrm{C}(11) \mathrm{H}_{2}\right), 1.81(1 \mathrm{H}, \mathrm{d}, J 10.0 \mathrm{~Hz}, H-5)$, $1.68(3 \mathrm{H}, \mathrm{s}, H-13), 1.14(3 \mathrm{H}, \mathrm{s}, H-15), 1.04(3 \mathrm{H}, \mathrm{s}, H-16), 0.88(3 \mathrm{H}, \mathrm{s}, H-14) .{ }^{13} \mathrm{C}$ NMR $\left(100.61 \mathrm{MHz}, \delta_{\mathrm{C}}\right): 175.4(\mathrm{C}-12)$, 136.0 (C-8), 131.1 (C-7), 76.2 (C-9), 68.7 (C-6), 51.9 (CO $\left.\mathrm{CO}_{2}\right), 49.2$ (C-5), 43.6 (C-10), 42.9 (C-3), 38.9 (C-11), 36.1 (C-15), 33.1 (C-1), 32.9 (C-4), 22.6 (C-14), 19.0 (C-13), 18.7 (C-2), 17.7 (C-16). HRMS m/z (EI): found 296.19777. $\mathrm{C}_{17} \mathrm{H}_{28} \mathrm{O}_{4}$ requires 296.19876. $296\left(\mathrm{M}^{+}, 3\right), 278$ (25), 263 (15), 207 (19), 193 (7), 172 (32), 154 (100), 135 (23), 121 (16), 109 (32), 98 (53), 81 (20), 69 (55), 55 (49), 41 (84). 


\section{Acknowledgements}

The author thanks to Academician P.F. Vlad and Doctors A. Ciocârlan and A. Barbă for their help in the realization of this work.

\section{References}

[1]. Jansen, B.J.M.; de Groot, A. Nat. Prod. Rep. 1991, 8(3), 309-318.

[2]. Jansen, B.J.M.; de Groot, A. Nat. Prod. Rep. 2004, 21(4), 449-477.

[3]. Kida, T.; Shiba, H.; Seto, H. J. Antibiotics, 1986, 39(4), 613-615.

[4]. Brooks, C.J.W.; Draffan, G.H. Tetrahedron, 1969, 25(14), 2887-2898.

[5]. Canonica, L.; Corbella, A.; Gariboldi, P.; Jommi, G.; Knepinsky, J.; Casagrande, G. Tetrahedron, 1969, 25(17), 3895-3902.

[6]. Kubo, I.; Makumoto, T.; Kakooko, A.B.; Mubiru, N.K. Chem Lett., 1983, 7, 979-980.

[7]. Ayer, W.A.; Pena-Rodrigues, L.M. J. Nat. Prod., 1987, 50(3), 408-417.

[8]. Urones, J.G.; Diez, D.; Gomez, P.M.; Mercos, J.S.; Basabe, P.; Moro, R.F. Nat. Prod. Lett., 1998, 11(22), 145152.

[9]. Urones, J.G.; Diez, D.; Gomez, P.M.; Mercos, J.S.; Basabe, P.; Moro, R.F. J. Chem. Soc., Pekin I, 1997, 12, 1815-1818.

[10]. Lopez, J.; Sierra, J.; Cortes, M. Chem Lett., 1986, 12, 2073-2074.

[11]. Vlad, P.F.; Coltsa, M.N.; Aricu, A.N.; Ciocarlan, A.G.; Gorincioi, E.C.; Edu, C.E.; Deleanu, C. Russ. Chem. Bull., Int. Ed., 2006, 55, 703-707.

[12]. Vlad, P.F.; Vorobieva, E.A. Chem. Nat.Compd. 1983, 148.

[13]. Koltsa, M.N.; Mironov, G.N.; Malinovskii, S.; Vlad, P.F. Russ. Chem. Bull., 1996, 45, 208.

[14]. Clennan, E.L. Tetrahedron, 1991, 47, 1343-1382.

[15]. Prein, M.; Adam, W. Angew. Chem., Int. Ed. Engl., 1996, 35, 477-494.

[16]. Stratakis, M.; Orfanopoulos, M. Tetrahedron, 2000, 56, 1595-1615. 